\title{
SYNTHESIS AND EVALUATION OF POSSIBLE SUBTYPE- SELECTIVE ANTAGONISTS OF NICOTINIC ACETYLCHOLINE RECEPTORS
}

\author{
Jhon J. López and Edwin G. Pérez \\ Mackenna 4860, Macul, Santiago, Chile \\ *e-mail corresponding author: eperezh@uc.cl
}

Department of Organic Chemistry, Faculty of Chemistry, Pontificia Universidad Católica de Chile, Vicuña

Keywords: Quinucludine, reductions, biological activity.

\section{INTRODUCTION}

Development of selective agonists or antagonists for the Nicotinic acetylcholine receptors (nAChR) may result in new and potentially useful therapeutic agents. It has been reported in the literature that potent and selective nAChR antagonists could be used for the treatment of nicotine dependence and may be an efficacious adjuvant therapy in many different oncologic protocols. ${ }^{1,2}$ nAChr antagonists studied previously by us having an indole ring core, $N^{1}$-alkyl groups and a quaternized moiety showed potency but little selectivity. ${ }^{3}$

\section{RESULTS AND DISCUSSION}

The synthesis of quinuclidines 1a-e was achieved as ilustred in Scheme 1. Quinuclidine-3-one hydrochloride and powdered anhydrous potassium hydroxide were dissolved in methanol and stirred for 15 mins, the corresponding aldehyde was then added in portions and the mixture was stirred for an additional $16 \mathrm{~h}$. The reaction mixture was then diluted with water and cooled to $0{ }^{\circ} \mathrm{C}$ yielding the corresponding vinylquinuclidinones as yellow precipitates. The vinylclinuclidinones were dissolved separately in methanol and $\mathrm{NABH}_{4}$ was added in portions with vigorous stirrer. After $1 \mathrm{~h}$, acetone was slowly added, the mixture was evaporated to dryness and the resulting residue suspended in water and extracted with chloroform and the organic phase was dried over anhydrous $\mathrm{Na}_{2} \mathrm{SO}_{4}$.to give the alcohol. The latter compound was converted to the chloro intermediate hydrochloride upon treatment with thionyl chloride. Dechlorination by hydrogenation with Raney nickel and carbon-carbon double bond reduction by hydrogenation over $10 \%$ palladium on charcoal was effected to yield the desired products.

The structure of one intermediate $(R=3$ methylbutyl) was confirmed by $\mathrm{X}$ ray study, figure 1 .

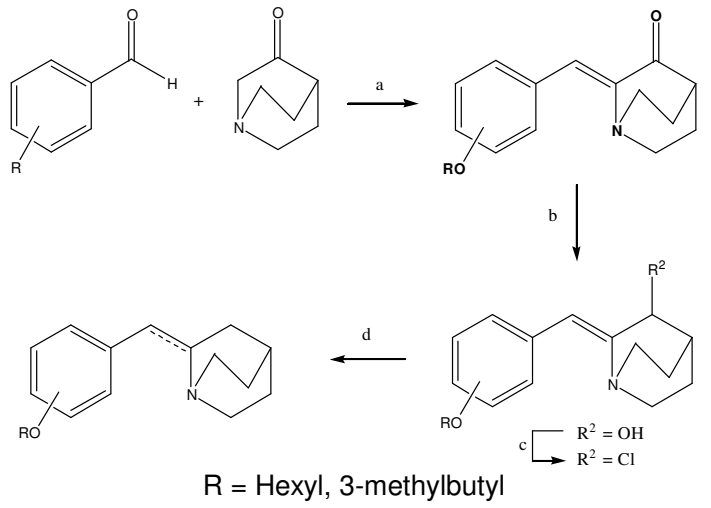

Scheme 1. Reagents and conditions: a. $\mathrm{KOH}, \mathrm{MeOH}$, rt., 16 h.b. $\mathrm{NaBH}_{4}, \mathrm{MeOH}$, rt, 1 h. c. $\mathrm{SOCl}_{2}$, rt, 1h. d. Raney $-\mathrm{Ni}, \mathrm{H}_{2}, 50$ psi, $\mathrm{EtOH}, 16 \mathrm{~h}$.

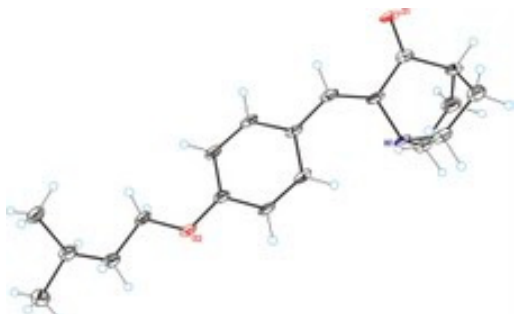

Figure 1. $\mathrm{X}$ ray structure for $\mathrm{R}=3$-methylbutyl.

\section{CONCLUSION}

Quinuclidine based new compounds were designed and synthesized using reported methodologies. Xray structure of one of them was determinate and the results of biological assays will be presented during the congress.

\section{ACKNOWLEDGEMENTS}

This work was supported by FONDECYT grant 11090120 and ICM grant P05-001-F.

\section{REFERENCES}

${ }^{1}$ Dasgupta, p.; Kinkade, R.; Joshi, B.; DeCook, C.; Haura, E.; Chellappan, S. Proc. Natl. Acad. Sci. U.S.A.., 2006, 103, 6332.

${ }^{2}$ Grozio, A.; Peleari, L.; Catassi, A.; Servent, D.; Cilli, M.;

Piccardi, F.; Paganuzzi, M.; Cesario, A.; Granote, P.; Mourier, G.;

Russo, P. Int. J. Cancer, 2008, 122, 1911.

${ }^{3}$ Pérez, E. P.; Eibl, C.; Gundisch, D.; Cassels B. K. Bioorg. Med. Chem. 2011. Acepted. 